\title{
Raising the Key Issues Facing Resettlement Practice in Development Induced Displacement: Evidences From Households Displaced by Railway Construction in Dukem, Ethiopia
}

\author{
Bikila Ayele Suyum (Corresponding Author) \\ Department of Sociology, Salale University, Fitche, Ethiopia \\ Tell: +251963903878_Ｅmail: ayelebikila@gmail.com
}

Received: July 22, 2019

Accepted: August 14, 2019

Published: August 14, 2019

doi:10.5296/jas.v7i3.15268

URL: https://doi.org/10.5296/jas.v7i3.15268

\begin{abstract}
Development projects are often resulted in massive displacement and resettlement of people. Despite the gradual improvement in resettlement practices and results, the impoverishments caused by development projects' displacement and resettlement are still widely observed in many developing countries. This study is intended to investigate the key issues facing resettlement practices based on experiences from households displaced by railway corridor construction in Dukem area, central Ethiopia. Data were collected by using semi-structured interviews, focus group discussions and archival file reviews. The study has revealed that policy, legal and practical factors were constraining effective resettlement and rehabilitation of the displaced households. The study indicates that the existing Ethiopian policy and legal frameworks on resettlement and rehabilitation of displaced people in the context of development projects were not effectively implemented in the study population context. The practice of valuation, compensation and expropriation were not fair and satisfactory mainly due to lack of objective criteria of evaluation, lack of technically competent valuation experts and widespread corruption in valuation and compensation of properties. The existing policy and legal frameworks on resettlement and rehabilitation of evicted people also lacks a clear statement on the livelihood rehabilitation of displaced households. The current compensation practice is monetary-based, inadequate, delayed and the rehabilitation approach lacks special consideration for vulnerable groups. Therefore, the researcher recommends the need for devising policy, legal and institutional frameworks which have clear provisions on how to deal with the multifaceted problems of displacement, resettlement and rehabilitation.
\end{abstract}


Additionally, ensuring effective reform to the structures of implementing agents of resettlement is very important.

Keywords: development-induced displacement, livelihood, rehabilitation, resettlement, Dukem, Ethiopia

\section{Introduction}

Development projects are often resulted in massive displacement and resettlement of people. Over the past 25 years, the World Bank estimates that more than 250 million people worldwide have been displaced from their residence and livelihood as a result of development interventions (World Bank, 2010). The recently growing investments in the name of development have increased the demand for land (Cernea, 1997; Termniski, 2013) for new industrial real states, for services, commercial estates, communications, roads, networks and for transportation corridors. According to Termniski (2013), in many developing countries, involuntary displacement and resettlement of people caused by construction of roads, highways, railways, ports and airports is currently one of the dominant forms of development induced displacement and resettlement (DIDR) and is taking place on all continents.

To accommodate such development projects, transferring a large amount of land for the needed project/investment activity becomes a necessity. However, much of land needed for such a purpose is already occupied by people that lead to displacement and resettlement of the land occupied population. The transfer of land through such a process affects livelihood of the displaced population if not properly resettled (Cernea, 1997; Robinson, 2003; World bank, 2010).

Despite the gradual improvement in resettlement practices and results, the impoverishment caused by development projects' displacement and resettlements is still widely observed in many developing countries (Vanclay, 2017). Many people who are displaced by development activities are not properly resettled and rehabilitated (Robinson, 2003; Cernea, 2008). Cernea (2008) indicated that many governments in developing countries have policies of compensation which is mainly dependent on cash compensation to rehabilitate people displaced by development projects as stipulated by their proclamations and legal frameworks. However, focusing on payment of cash compensation has limited capacity to improve and/ or restore the livelihood of the displaced households. Cash compensation is inadequate to re-establish livelihoods and other social losses. He argued that remedy to compensate the loss due to forced acquisition through monetary compensation without consideration of other social consequences is inadequate to regain lost livelihood.

In Ethiopia, displacement of people due to development projects and investments aimed at economic growth and social transformation is common (Eguavoen \& Tesfai, 2012). The large scale, and rapidly increasing of forced displacement in the name of development has been displaced many rural people where the displaced are uprooted from rural areas and relocated to urban areas. This exposes the displacees to unaccustomed urban livelihood and causes further livelihood risks and impoverishments. This problem could be managed by adopting 
and implementing effective resettlement and rehabilitation practice. Few studies (Belachew, 2013; Muradu, 2015; Daniel, 2013; 2014; Gashaw, 2015; Wubante, 2014) have been conducted in Ethiopia on expropriation, valuation and compensation policies and/or legal provisions and practices in Ethiopia. The studies have revealed that there are gaps at policy and legal provision level, and practical bottlenecks on the implementation of the existing policy and laws. The studies showed that there is a gap of policy and legal provision on an expropriation, valuation and compensation of displaced households' properties.

This study mainly focuses on the key issues facing the resettlement and rehabilitation of the livelihood of households displaced by development projects in urban fringes. The displacement of households in this context involves relocation of urban vicinity farm households to urban life, which exposed the displacees to socioeconomic challenges of unaccustomed urban livelihoods. The previous studies didn't pay attention to the problems facing households shifted from rural life to urban livelihood which is increasing from time to time in Ethiopia. To fill this gap, the study is primarily intended to investigate the challenges facing resettlement of the households displaced by Addis-Djibouti railway corridor construction in the case of Dukem area, Oromia, Ethiopia.

\section{Materials and Methods}

The Population of the Study: The target population of the study was all the 230 households displaced by Addis-Djibouti railway corridor construction in Tedecha Kebele of Dukem town.

Research Setting: This research is conducted in Dukem area, Oromia region, Ethiopia in 2014 (Figure 1). Dukem is located at 37 kilometers South East of Addis Ababa. The astronomical location of the town is located between $8045^{\prime} 25^{\prime \prime} \mathrm{N}-8050$ '30"N latitude and 38051'55"E - 38056'5" E longitude.

Research Design and Methods of Data Collection: In this study, qualitative cross-sectional design was used. Both primary and secondary data were collected by using semi-structured interview, in-depth interview, focus group discussions (FGDs) and archival review.

In-depth Interview: In-depth interview was held with key informants by using unstructured questions. In this study, 12 displaced household head, 3 local elders, 3 administration officials and 2 extension workers were interviewed.

FGD: 2 FGDs consisting 12 discussants in each group were conducted with heads of displaced households to collect data on the overall resettlement and rehabilitation experiences of the households.

Semi-structured interview: Semi-structured questions consisting of both open-ended and close-ended questions were utilized to collect data from 70 displaced households.

Sampling Design and Sampling Technique: Non-probability sampling method was used to select the sample respondents. From non-probability sampling methods, convenience sampling method was used to select the sample of the study. 
Methods of Data Analysis: The data was analyzed qualitatively. Qualitative data gathered through semi-structured questions, in-depth interviews and FGDs were grouped thematically, categorized, organized and analyzed. Finally, the qualitative data findings were compared with previous researches to reach conclusions.

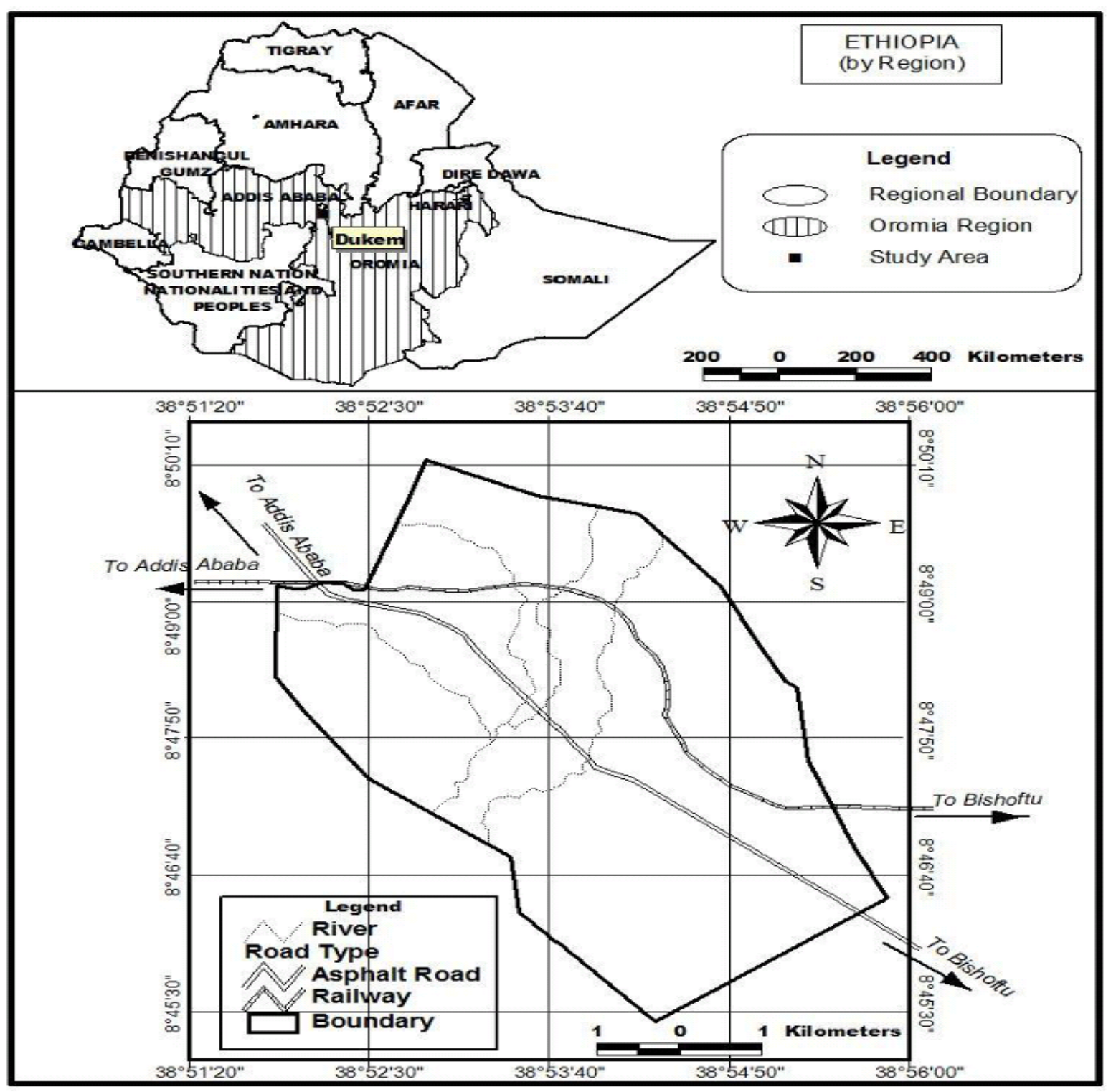

Figure 1. Location of the study area

\section{Development Induced Displacement, Compensation and Resettlement}

Downing (2002) indicated that the term displacement is used most often in the context of relocation related to deprivation of access to existing land and its resources, unaccompanied by adequate support mechanisms for the affected people and involves physical eviction from a dwelling and the expropriation of productive assets to make possible an alternative use. The phenomenon of displacement is thus not limited to physical dislocation from the current residence, but is mainly associated with the loss of existing economic and social facilities and of access to the relevant resources, with no benefits gained in return. Cernea (1996) further 
explained that displacement is mostly applied to the situation of individuals, tribes and communities that have been cut off from their current socioeconomic base and as a result have seen their standard of functioning deteriorate significantly. Cernea (2000) argued that displacement can be experienced in many forms, including the people who realize less benefit as a result of the development process and those who face severe consequences and for those individuals and communities who involuntarily move leaving behind homes, networks, jobs, social capital and emotional ties to place. Relocation refers to the physical shift of individuals or groups from their usual home (place of origin) to another location (place of relocation). According to Robinson (2003) resettlement may be voluntary or involuntary, as in case of migration of people from places of origin in the search of better economic opportunities in other places or involuntary, as happened with the forced displacement of people due to violent conflicts, may be temporary or permanent. He added that voluntary movement can also contain the elements of coercion just as involuntary movement is not without rational decision making strategic choice.

\subsection{Development-Induced Displacement}

Development-induced displacement can be defined as the forcing of communities and individuals out of their homes, often also their homelands, for the purposes of economic development. Use of coercion or force of any nature by state is central to the idea of development-induced displacement (Dhru, 2010). Implementation of development projects often leads to development induced displacement. According to Cernea (2003) displacement can start before people are physically removed from their residence by legally stopping construction, entrepreneurial investment, and public infrastructure investments. This makes households suffer economically before actual eviction from their land/houses and eventually leads them into impoverishment risks. Cernea (2000) revealed that displacement can be experienced in many forms, including the people who realize less benefits as a result of the development process and those who face severe consequences and for those individuals and communities who involuntarily move leaving behind homes, networks, jobs, social capital and emotional ties to place.

\subsection{Compensation and Rehabilitation}

Compensation often refers to payment in cash or in kind or both for a property or other resources acquired or affected by a project (may include land, house, plans and business) (Downing 2002). Rehabilitation refers to re-establishing incomes, livelihoods and social systems of the displaced people to the standards prior to displacement (Fernandes, 2008). Rehabilitation is a long time process that involves rebuilding people's physical and economic livelihood, their assets, their cultural and social links and psychological acceptance of a changed situation (Cernea, 1996; World Bank, 2004). Rehabilitation is a very important aspect in the whole process of resettlement and can either lead to successful resettlement or a failure with regard to livelihood improvement and/ or restoration (Cernea, 1996; Downing 2002; Kemp et al. 2017). Rehabilitation can be envisaged as a process that would reverse the risks of resettlement. The proponents of displacement and resettlement studies denote that rehabilitation is supposed to begin prior to physical population displacement. 
3.3 Guidelines and Frameworks for Addressing Development Induced Displacement

Olawepo (2008) indicated that Africa's development has been largely influenced by international financial institutions such as the World Bank and International Monetary Fund. In their attempt to attract development assistance and foreign investments, many African and Asian governments have been compelled to agree to large infrastructure, industrial and dam projects in the name of the development. The influence of global institutions in developing countries' development has therefore necessitated the consideration and adoption of global policies, principles and frameworks that exist for managing the adverse impacts of development projects.

A study conducted by the World Bank (2004) shows that involuntary resettlement under development projects, if unmitigated, often gives rise to severe economic, social, and environmental risks. To decrease these negative impacts caused by involuntary resettlement International Financing Agencies including the World Bank in 1980 and the African Development Bank in 2003 have developed policy guidelines for managing involuntary resettlement resulted by development projects. According to the World Bank (2004), any bank-financed project that involves land acquisition should be reviewed for potential resettlement requirements early in the project cycle. The World Bank Resettlement Policy emphasizes that project planning must avoid and minimize involuntary resettlement, and that if people lose their homes or livelihoods as a result of Bank-financed projects, they should have their standard of living improved, or at least restored.

The FDRE has developed a legal framework for expropriation and compensation for development Projects. The legal frameworks of Development Projects are based on the Constitution of FDRE and World Bank Operational Policies on Involuntary Resettlement. The Constitution of the FDRE has several provisions which have direct policy, legal and institutional relevance to the appropriate implementation of the resettlement plans prepared by development projects and programs. Article 44 No.2 of FDRE Constitution states that "All persons who have been displaced or whose livelihoods have been adversely affected as a result of state programs have the right to commensurate monetary or alternative means of compensation, including relocation with adequate state assistance."

The Constitution also guarantees people whose livelihood is land based and pastoralists have the right to have access to land as well as protection against eviction from their possession (Article 40.4 and 40.5). Article 40.8 also states that; "Without prejudice to the right to private property, the government may expropriate private property for public purposes, subject to payment in advance of compensation commensurate to the value of property."

\section{Results and Discussions}

Effective resettlement and livelihood rehabilitation strategies in development induced displacement are crucial to prevent and/or minimize risks and impoverishments after displacement. The policies, laws and institutions of resettlement in forced eviction and their implementations determine the degree to which affected people recover from livelihood impoverishments. The issue of resettlement of displaced people in development projects has 
been provided in the FDRE constitution, policies, proclamations and regulations. Ethiopia is also a member of the Bank Group and ratified regional and international guiding principles of forced displacement in the context of development projects.

Studies (Mathur 2006; World Bank 2012, 2014; Smyth et al. 2015 in Vanclay, 2017) on involuntary resettlement practices indicate that many resettlement interventions have been facing shortcomings such as shortage of time, inadequate budget for resettlement and compensation, cash based compensation, lack of competent expert of property valuation, a poor assessment of project and project affected people, poor management of the cutoff date, poor participation of impacted people and poor awareness. This research discusses the findings related to the challenges and/or key issues facing the resettlement and rehabilitation of households displaced by Addis-Djibouti railway corridor construction in Dukem area.

\subsection{Problems Related to Valuation and Compensation}

\subsubsection{Unfair Valuation of Properties}

In-depth interviews and FGDs results indicate that many of the displaced households feel that the process of valuation and compensation was unfair. The respondents/discussants were asked why the valuation and compensation was not fair, and they stressed that the valuers of their properties favored those who pay bribes and there was widespread corruption related to property valuation. The key informant from the Dukem town administration also indicated that corruption during valuation process, lack of technical knowledge about the valuation of property, lack of awareness about their rights on the side of the displaced households were the serious challenges to the process of property valuation and compensation.

World Bank principles clearly provide that "There should be transparent and justifiable mechanisms to calculate the replacement value of all assets, and the date for calculation should not be the date of the original notification, but instead the date on which the compensation is actually disbursed. Cash compensation must be minimal, excepting where it is a preferred option of the people. All assets must be replaced and the cash component must be in the name of the oldest male and female member or the male and female heads of household. People who are to be relocated must be fully compensated before physical relocation from land, house, or livelihood is executed. The resettlement plan must provide for full disbursement of compensation a year prior to any physical dislocation. If the relocation is delayed, then there must be a provision to pay interest on the compensation that is made in order to account for inflation and other escalations in the cost of replacement" (World Bank Guiding Principles in Bartolome, et al, 2000). Additionally, the guiding principles of the bank dictate the need for providing information on the process of resettlement and rehabilitation, the rights and entitlements, participation in resettlement and providing resettlement options and strategies.

African Development Bank policy on involuntary resettlement states that the policy is basically aimed to "ensure that the disruption of the livelihood of people in the project's area is minimized, ensure that the displaced persons receive resettlement assistance so as to improve their living standards" (African Development Bank, 2003). Ethiopia has also 
domestic policy and laws to protect forcefully evicted people, which focus on the core principles of preventing eviction if possible and minimizing risks if displacement is compulsory.

The current policy and legal frameworks of involuntary displacement in Ethiopia fails to adhere to the international instruments, basic principle which states, countries should adopt, to the maximum of their available resources, appropriate strategies, policies and programs to ensure effective protection of individuals, groups and communities against forced eviction and its consequences. Few researches (Belachew Yirsaw, 2013; Muradu Abdo, 2015; Daniel Weldegebriel, 2014; Gashaw Tanna, 2015) conducted on evaluation of properties in development induced expropriation of properties reveal this fact. These researchers indicated that implementation of Ethiopian expropriation policy marginalizes and not friendly to urban vicinity households (Gashaw Tana, 2015). Muradu Abdo's (2015) finding also indicates that the government takes land from small holder farmers where expropriation laws are inadequate to protect peasants and pastoralists. The above evidences and the findings of this research indicate that urban vicinity households often receive unfair compensation for lost properties.

\subsubsection{Inadequate and Delayed Compensation}

The research findings revealed that the compensation payment given to the displaced households was inadequate and delayed. Respondents were asked why the compensation was inadequate. Among the repeatedly mentioned reasons were the replacement cost was too inadequate to construct house and restore permanently lost assets such as land, trees, garden fruits and other destructed properties. The replacement land given for house construction is very small as compared to previous compounds of the displaced households and delayed for more than eight months after the displacement.

The compensation process also failed to consider the inflation in the market price of building materials. FGD discussants and key informants mentioned that the compensation for lost income generating properties such as trees, fruits and garden vegetables were underestimated and unsatisfactory. Moreover, the delay of replacement land for house construction has weakened household's capacity to construct house. Majority of the displaced households started house construction after ten months of the displacement due to delay of land compensation. This created an increase in the price of construction materials which affected the financial capacity of many households to construct residential house. One of the displaced households viewed the delay of compensation and inadequacy as follows;

"The committee of property evaluation has underestimated my properties and the money they gave me for estimation of my house and other garden properties couldn't construct a house in this new place; even it couldn't construct half of my previous house. I started constructing this new house before three months, but I couldn't finish even one third of it because the construction materials' price is doubled as compared to its cost of the last year when our property was evaluated. The replacement land for house construction was delayed. Now the cost of everything is increased; labor cost and construction material cost is increased". 
According to key informants, the delay of the replacement land also contributed to the misuse of the compensation money as some of the households spend their money on individual and household's consumption, others spend on unnecessary expenses. One of the key informants explained his experience of misuse of the compensation money as follows:

"Many household heads finished the compensation money on unnecessary expenditure before constructing their house. Many spent the money on buying clothes, home materials such as television, seats and other costly materials. There were many household heads who spend the whole day in tella and areke house. At the beginning the compensation money seems too much to cover all the needs of the households. But after a year, we all recognized that the money could be finished in a month if not properly used. The whole year, we draw out the compensation money from bank small by small to cover family expenditure and for food consumption. This condition weakened many households' capacities to construct house."

Generally, the study indicated that the compensation money and replacement of land for house construction are inadequate and unsatisfactory. The money compensation was not adequate to construct a new house. This is basically due to two reasons. First, the items of compensation were under estimated as the evaluators underestimated the market price of items of compensation. The second is the replacement land for house construction was delayed for more than eight months and the market price of construction materials was highly increased by the time land for house construction is given. Moreover, the compensation money was spent on household subsistence and some households extravagantly misused the money spending on unnecessary expenditures. The sum of these problems resulted in households' failure to construct houses on time and the money were not converted to productive assets rather spent on immediate household's consumption letting the future livelihoods of many households in risks.

Serene (2000) indicated that the success of a resettlement project often depends primarily on the implementation of effective and adequate compensation. In responsible resettlement/relocation of displaced people, compensation is seen as a continued process of redressing the loss caused by relocation. Proclamation number $455 / 2005$ provides "a rural land holder whose land has been expropriated shall, in addition to the compensation payable under article of be paid as displacement compensation which shall be equivalent to ten times the average annual income secured during the five years preceding the expropriation of the land". Therefore, compensation for rural land and properties is very low to ensure the resilience of livelihood. This supports Gashaw (2015) and Wubante (2014) findings in which they argued that compensation payment in Ethiopia is too little to sustain livelihood after eviction.

\subsubsection{Money Based Compensation}

Another important issue in understanding the effectiveness of compensation is the form in which the compensation is received by displaced or affected communities. One of the indicators of the inefficiency of compensation is cash based compensation. As indicated in literatures, cash compensation could not satisfy the multidimensional aspects of livelihood. Cernea (1996, 2003 \& 2008) point out that many governments in developing countries have 
often adopted policies of compensation which mainly depend on monetary compensation to the displaced people. However, reliance on cash compensation has often limited capacity to improve and/ or restore livelihood of the displaced households because cash compensation alone could not rehabilitate the livelihoods of displaced households.

World Bank (2004) guiding principle clearly states that "DPs losing access to less than 20 percent of their landholding can be paid cash compensation at replacement cost for the portion of land lost to them". This indicates that in case displaced people are losing access to more than 20 percent of their land holdings, compensation should include non-financial rehabilitation schemes to reduce risks of displacement and restore livelihood at least to its previous standard.

A weakness of the compensation approach utilized in the study context is that it offers cash compensation for the land being acquired for the project and rehabilitation of affected/displaced people does not get attention. Little emphasis is given to non-financial compensation and rehabilitation of affected households. The proclamation No. 455/2005 of Ethiopia gives emphasis on process of cash compensation while no clear provision was given to intervention of non-financial aspects and rehabilitation of displaced households to ensure effective restoration of livelihood of displaced households.

In this study, the problem of cash compensation is clearly observed that it leads to improper expenditure by individuals and/or households who are unaccustomed to large amounts of money. According to key informants, the displaced households drive their earning fully or partially from agriculture and they are neither accustomed to handling large amount of money nor skilled enough to convert the money into productive assets. One of the key informants said;

"The majority of these people are farmers, laborers, cart drivers who were not familiar with large amounts of money. They have low levels of education and low skill of money management. Only few individuals effectively converted the money into productive business and construct houses on time. The big problem is that, there is no proper training given to displaced households to properly use the money and the government did not follow up what families are doing with the money after they were given the compensation money."

Though the policy and legal frameworks state the processes of monetary compensation, the non-financial aspects of compensation such as proper relocation place for socioeconomic rehabilitation, retaining the social networks in a new location, follow up of the compensation money usage, retaining old model of economic activity and giving support for special need group such as female headed households, households with no productive members and poor households are not clearly provided. Although the town and the woreda administration are supposed to be responsible to look after such conditions, the case of the study area displaced people indicates that they rarely address these issues.

The study indicated that among the displaced people, many of them were farm households and others partially engage in agriculture. In such a condition, depending on money compensation alone exposes the households to risks. According to focus group discussions, 
the displaced households were convinced to get proper training on the use of cash compensation, to be provided with sustainable income sources where they unable to continue their old job. After displacement, however, none of these promises changed into action and no tangible non-financial compensation/interventions were given to displaced households to cope up with upcoming risks and impoverishments of the displacement. According to one of the interviewees, non-financial provisions promised by the government were not implemented. One interviewee said;

"They gave us the money of compensation and thrown us to rent a house where we troubled for a year without proper follow up from the administration. The promised training of households for new job couldn't be continued than few days talk at meetings. The promised job training in micro finance association was forgotten after dislocating us from our previous residence."

Though the money was given through a bank account in the name of both husband and wife to minimize household head dominance in the management and misuse of the money; the study revealed that husband heads still dominate women and children's decision on the household's subsistence needs and expenditures. This condition increased unnecessary use and expenditure of the compensation money. It was also observed that the resettlement program unable to resettle the affected people in areas similar to the previously inhabited in terms of the mode of economic activities, and couldn't allow them to follow their accustomed socioeconomic model. The land for land compensation for farm households and giving consideration for suitability of the new location of residence for nonfarm activities were not practically implemented.

In this research, the compensation was money-based and lacks long-term socioeconomic support mechanisms (livelihood rebuilding) such as trainings for new skills and jobs, and creating conducive environment for mutual support i.e. supporting social capital. This posed affected households to short and long term socioeconomic risks and impoverishments such as joblessness, food insecurity and social disarticulation. Generally, the study shows that the resettlement of the displaced households was focused on cash compensation and the cash compensation itself was not properly delivered in a way to rebuild the displaced households' livelihoods.

\subsection{Lack of Special Consideration for Vulnerable Households}

The Ethiopian proclamation and regulations on displacement and resettlement have no clear provision for assisting highly vulnerable households such as poor land based farm households, the aged and female headed households who can't construct houses and engage in productive income earning activities. The vulnerable displaced households didn't get any special treatment/support to cope up with displacement caused socioeconomic challenges of livelihood. For this purpose, I have conducted interviews with concerned officials and displaced households. The proclamation and regulations on resettlement have no provision/s of special intervention for highly vulnerable groups, but the words and the town administrations have the responsibility to follow up such groups. One of the officials of the Dukem town land administration office said; 
"We have no special intervention for special need households because we need to follow the proclamation and regulation of compensation and resettlement. The town administration have the responsibility of organizing them in microenterprises and providing them special trainings to enable them engage in income earning jobs. Displaced households with special needs such as jobless youth, female headed households, and poor families often organized in micro enterprises and urban agriculture after giving them short term trainings, so that they can engage in income earning activities and improve their livelihood. However, due to inconveniences of time, human power and money, such interventions are delayed."

Poor households and jobless youth who have no land, wealth, skill or education to engage in a new job became vulnerable to livelihood risks. Households with non-productive members are also the most vulnerable group in the study area. According to a 65 year aged respondent, households with old aged and non-productive members couldn't finish house construction and face difficulty of engaging in income earning activities. He stated his own experience as follows;

"I was very poor even before displacement and I have no children to support me, my wife is also old aged and we both rent our small plot of farmland to earn our living. However, after the displacement, I lost my basic source of living, the land. I have lost my base. I can't construct house because I have no physical strength to do so and nor does my wife. We have no nearby relative to help us. The money of compensation has been used for consumption and for health follow up. I have health problems and I spend on health treatment regularly. The money could be finished in a short period of time before we construct a house."

One of the key principles of international and regional involuntary resettlement policies is assistance to affected people to sustain their livelihood which is absent both in policy and practice in the Ethiopian context. World Bank (2004) indicated that involuntary resettlement often affects vulnerable groups such as poor, women, children, the handicapped, the elderly and indigenous populations more severely than those that have better wealth. However, the extent, nature, and severity of exposure to development induced displacement risks and impoverishments vary among these vulnerable groups. Therefore, resettlement planning needs thorough identification of categories of displaced populations in project design and pay attention to the resettlement needs of highly vulnerable groups to reconstruct their livelihoods. Most of these vulnerable groups are not protected by national compensation laws. This research also indicates that many of the elderly, disabled, female headed households and poor displaced households became vulnerable.

\subsection{Lack of Actual Intervention to Restore Livelihoods and the False Promises}

Prior to displacement of people from the right of way (ROW), the displaced households were called for a meeting several times to discuss about the displacement, compensation, where to relocate, services to be fulfilled in the relocation village and livelihood rebuilding strategies to be implemented to restore livelihoods of the displaced people. Accordingly, the displaced households were promised to have adequate social services and means of income generation that is going to be fulfilled in a few months after the dislocation. The promised services 
include electricity, water, road, and organizing displaced households in various micro level income earning activities and urban agriculture. One of the FGD discussants said;

"Before the displacement, the officials told us that all the required services will be fulfilled in the coming few months and then we will have a better access to services than we had then. However, they are kidding us like a child. After relocating us, let alone fulfilling the promises; it took them eight months to give us land for house construction. After that time, we asked them about the services and they replied to us that the participation and money contribution from the displaced households is mandatory. Each household paid 1600 Ethiopian Birr only for water, electricity and road. Unfortunately, till this time, the town administration remains silent and none of these facilities are fulfilled."

The displaced households were also promised to get trainings and organized in micro level enterprises of varying types right after the displacement, that was suggested to be a solution to the joblessness of the displaced households. According to key informants, registration of the displaced households for micro enterprises and urban agriculture was started during the dislocation. However, the promises couldn't be fulfilled after the displacement. Although such interventions have a great capacity to solve the problems of joblessness and income insecurity, none of them changed into action. The other unfulfilled promise was land for land compensation for house construction which was promised to have the same size with the previous house/compound. However, the land for land compensation was too small for almost all respondents compared to the size of their previous compounds.

It is also difficult for the displaced households to shift their residence to self-constructed house in the relocation village because there are no basic social services such as water, electricity and road at all in the village; though the people collected money for the fulfillment of these services. Few households who have already shifted to the new resettlement village are using fire wood and candle for light; and bring water from very far distance village by cart and donkey back. The area is also prone to flooding as the place is a plainly lowland where flood from different directions sleep on.

The study revealed that the failure to rehabilitate displaced household livelihoods is attributed to two basic factors. The first is external factors such as poor compensation and rehabilitation strategies and weak implementation of the existing resettlement policy and legal frameworks. The second is internal factors such as household's main source income, level of education, level of wealth before displacement and size of productive member composition. The package of resettlement programs and compensation strategies adopted by the government seems to fail to consider issues such as proper household destiny of residence after displacement, retaining secured income and effective use of compensation money.

The displaced households were forced to leave the area of a right of way in time less than two months after being informed about the displacement. This implies too short period of time for households to adjust themselves to moving to a new location or prepare themselves to search for a new place of residence and means of earning. Households need time to search for house to be rented with needed size for the household size and property. 
Moreover, moving farm households to rent house can be seen as a big fault of the resettlement process. This is mainly due to the fact that farm households often have large family members, food crops, livestock of different types such as cattle, ship, goat and home animals like dog and cat. These properties need to move to rent a house, but it is very difficult because most of the rent houses are small in size while such large properties need a large compound which is often unavailable in the area and too costly if available. The displaced households were not given enough time for looking for residence house that suit their family and property size, and consider their options for socioeconomic re-establishment. This indicates two basic problems; the first one is the fact that the proclamation and regulations provide such a short time; three months for farm households with properties to move from the site and one month for non-farm households which is too short for households even to determine where to live and what to do to earn a living. In addition, giving one year money for a rent house could not guarantee availability and access of rent house which goes with socioeconomic life of the displaced households. The second is a poor practical implementation of resettlement, compensation and rehabilitation. Although positive approach such as immediate fulfillment of social services and sufficient compensation were promised before displacement as discussed above, these promises found to be reversed after removing the households from their home/residence.

\section{Conclusions}

The study was intended to assess the challenges of resettling households displaced by Addis-Djibouti railway corridor construction in Dukem area. The study found that the resettlement and livelihood rehabilitation schemes have weaknesses and faced problems of effective implementation in the study context. The current proclamation and legal frameworks of Ethiopia lacks clear provision about proper rehabilitation and intervention before, during and after displacement to minimize the risks and impoverishments of displacement and to restore displaced household livelihoods after displacement.

The study revealed that the compensation frameworks focus on monetary compensation neglecting non-financial aspects livelihood rehabilitation of the households. The compensation of money and land for house construction are found to be inadequate and delayed. The resettlement frameworks also fail to deal with highly vulnerable households who absorb the negative impacts of the displacement. Vulnerable groups such as poor farm households who lost their farm land, households with no productive members, elderly and poor female headed households were unable to secure a sustainable source of income, unable to construct houses and exposed to impoverishment risks. Farm households were shifted to rent houses where they faced problems of taking their live stocks and other properties with them, which is resulted in sell of live stocks and loss of other properties due to lack of own compound. Households who depend fully or partially on agriculture became jobless and lost their basic income sources.

The displaced households were promised to get full social services, trainings for new jobs and better income sources in the relocation village. However, none of the promised social services were provided after displacement. 
Generally, the Ethiopian policy, legal and institutional frameworks on resettlement and displacement have huge gaps as it focuses on monetary compensation, fail to consider highly vulnerable group, provides marginal compensation and lack clear provisions on rehabilitation strategies. Moreover, the current policy and legal frameworks implementation are very poor, resulting in inadequate and delayed compensation, false promises by local administrators, corruption and unfair compensation of properties and lack of basic infrastructures for the affected households.

\section{Recommendations}

The following recommendations are forwarded to concerned stakeholders to minimize the risks of displacements and maximize effective rehabilitation of affected peoples.

The government needs to develop development policy that protects the interests of the affected people. The policy, legal and institutional frameworks need to adopt clear provisions which include proper intervention before, during and after displacement. The frameworks need to have mechanisms of effective relocation/resettlement scheme to ensure effective rehabilitation of displaced households.

The policy and legal provisions of compensation should not be focused on cash compensation. It should rather focus on non-monetary forms of compensation and effective rehabilitation strategies after displacement. Compensation policy should be broadened beyond cash compensation and other alternatives of livelihood building along money compensation must be devised. There should be ways of training in a new income earning and awareness of management of compensation money so that they can convert it to productive assets.

$>$ Compensation and resettlement schemes need to have mechanisms of treating the differential impacts of displacement on displaced households. In urban vicinity displacement the mix of farm and nonfarm households treated equally though farm households consume the adverse effects of displacement. There should be mechanisms of helping the most vulnerable groups such as poor land based farm households, households with no productive members, the elderly, disabled, female headed households.

Displaced households need to be consulted and participated in the planning of displacement and resettlement. They also need sufficient time to prepare themselves and adjust their livelihood to the impacts of displacement.

$>$ Implementing agency; districts/town administration should plan for job creation for sustainable employment of the displaced population to reduce and /or avoid the risks of joblessness. The affected population needs to be provided with training and capacity building projects and linked with micro level enterprises to enable them access sustainable job opportunities and income sources.

Compensation should be adequate, timely and impartially evaluated. Thus, compensation should be sufficient enough to enable households construct houses and start their own 
business to earn income at minimum. The evaluation committee should be well trained, and impartial in evaluation of properties.

\section{Limitation of the Study and Future Research Direction}

The findings of this research are purely qualitative and it only represents the experiences of the study population. Therefore, I would not dare to generalize the findings of this research to the larger population evicted by the same project in the same year. I believe that longitudinal research on the changes of the practice of resettlement and rehabilitation is needed. The long term positive changes experienced in such resettlement and the agency of the resettled people need further research.

\section{Statement of Declaration}

I declare that I have no significant competing financial, professional, or personal interests that might have influenced the performance or presentation of the work described in this manuscript. 


\section{References}

African Development Bank, (2003). Involuntary Resettlement Policy. https://www.afdb.org

Bartolome, L. J., de Wet, C., Mander, H., \& Nagraj, V. K. (2000). Displacement, Resettlement, Rehabilitation, Reparation, and Development, WCD Thematic Review I.3 prepared as an input to the World Commission on Dams, Cape Town, www.dams.org

Belachew, Y. (2012). Expropriation, Valuation and Compensation Practice in Amhara National Regional State (ANRS) - The Case of Two Cities (Bahir-Dar and Gonder), Nordic Journal of Surveying and Real Estate Research, 9(1), 30-58.

Belachew, Y. (2013). Expropriation, valuation and compensation practice in Ethiopia: The case of Bahir Dar city and surrounding. Emerald Group Publishing Limited, 31(2), 132-158. https://doi.org/10.1108/02637471311309436

Cernea, M. (1996). Public policy responses to development induced population displacements. Econ. Polit. Weekly, 31, 1515-1523.

Cernea, M. (1997). The risk and reconstruction model for resettling displaced populations: World Development, 25(10), 1569-1587. https://doi.org/10.1016/S0305-750X(97)00054-5

Cernea, M. (2000). Risks, safeguards and reconstruction: a model for population displacement and resettlement. Econ. Polit. Weekly, 35, 3659-3678. https://doi.org/10.1596/0-8213-4444-7

Cernea, M. (2003). For a new economics of resettlement: a sociological critique of the compensation principle. Int SocSci J., 55, 37-45. https://doi.org/10.1111/1468-2451.5501004

Cernea, M. (2008). Compensation and benefit sharing: why resettlement policies and practices must be reformed. Water Sci Eng., 1, 89-120. https://doi.org/10.1016/S1674-2370(15)30021-1

Cernea, M. (2008). Compensation and investment in resettlement: Theory, practice, pitfalls and needed policy reform, [In] Cernea, M. Mathur, H.M. (eds.), can compensation prevent impoverishment?: Reforming resettlement through investment and benefit sharing, Oxford University press, New Delhi, PP. 15-99.

Daniel, W. (2013). The History of Expropriation in Ethiopian Law. Mizan Law Review, 7(2). https://doi.org/10.4314/mlr.v7i2.4

Daniel, W. (2014). Compensation for Expropriation in Ethiopia and the UK: a Comparative Analysis. FIG Congress, Engaging the Challenges Enhancing the Relevance: Kuala Lumpur, Malaysia, June, 16-21. www.fig.net/pub/fig2014/papers/ts01f/TS01F_ambaye_6821.pdf

Dhru, K. (2010). Acquisition of land for development projects in India: The Road Ahead: Gurath, Research Foundation for Governance. ISBN Number: 81-901203-0-6. https://www.rfgindia.org/publications/LandAcquisition.pdf

Downing, T. E. (2002). Avoiding new poverty: Mining-Induced Displacement and Resettlement. Mining-Induced Displacement and Resettlement. https://pubs.iied.org/pdfs/G00549.pdf 
Eguavoen, I., \&Tesfa, W. (2012). Social Impact and Impoverishment Risks of The Koga Irrigation Scheme, Blue Nile basin, Ethiopia: AFRIKA FOCUS - Volume 25. Pp.39-60

FDRE, (1995). Expropriation of landholdings for Public Purposes and Payment of Compensation Proclamation No. 455/2005. (Accessed on February 12, 2013). http://faolex.fao.org/docs/pdf/eth135247.pdf

FDRE, (1995). Federal Democratic Republic of Ethiopia Constitution. Addis Ababa, Ethiopia.

Fernandes, W. (2008). India's Forced displacement policy and practice: Is compensation up to its function? In: Cernea, M.m\&Mathur,H.M, (eds), 2008, Can compensation prevent impoverishment? Reforming resettlement through investments and benefit sharing. Oxford University Press, New Delhi. http://onlineministries.creighton.edu/CollaborativeMinistry/NESRC/Walter/chp-7.pdf

Gashaw, Tenna (2015). Land Expropriation and Compensation Payment in Ethiopia: Review, Journal of Economics and Sustainable Development, ISSN 2222-1700 (Paper) ISSN 2222-2855 (Online), 6(13).

Kemp, D., Owen, J., \& Collins, N. (2017). Global perspectives on the state of resettlement practice in mining. Impact Assessment \& Project Appraisal, 35, 22-33.

https://doi.org/10.1080/14615517.2016.1271544

Muradu, A. (2015). Reforming Ethiopia's Expropriation Law: Mizan Law Review, 9(2), https://doi.org/10.4314/mlr.v9i2.3

Olawepo, R. A. (2008). Resettlement and Dynamics of Rural Change in Jebba Basin, Nigeria. Journal of Social Science, 16(2), 115-120. https://doi.org/10.1080/09718923.2008.11892607

Robinson, W. C. (2003). Risks and Rights: The Causes, Consequences and Challenges of Development Induced Displacement. The Brookings Institution. Washington DC. https://www.google.com/url

Terminski, B. (2013). Development-Induced Displacement and Resettlement: Theoretical Frameworks and Current Challenges; Geneva. https://doi.org/10.2139/ssrn.2201987

Vanclay, F. (2017). Project-induced displacement and resettlement: from impoverishment risks to an opportunity for development? Impact Assessment and Project Appraisal, 35(1), 3-21. https://doi.org/10.1080/14615517.2017.1278671

World Bank, (2004). Involuntary resettlement: planning and implementation in development projects. Washington (DC): World Bank; Available from:

https://doi.org/10.1596/0-8213-5576-7

World Bank, (2010). Rising Global Interest in farmland: Can it yield sustainable and equitable benefit? New York: The World Bank. 


\section{Macrothink}

Journal of Agricultural Studies

ISSN 2166-0379 2019, Vol. 7, No. 3

Wubante, F. (2014). Acquisition of Land Holdings and Compensation Practice in Ethiopia: Amhara Region - Bahir Dar City Surrounding Farming Area. Paper Presented at the Innagural Conference on Land Policy in Africa, Addis Ababa, Ethiopia. November 11-14.

\section{Copyright Disclaimer}

Copyright for this article is retained by the author(s), with first publication rights granted to the journal.

This is an open-access article distributed under the terms and conditions of the Creative Commons Attribution license (http://creativecommons.org/licenses/by/4.0/). 